\title{
トンネル覆エの定量的な健全度評価手法 に関する検証
}

\author{
海瀬 忍 1 ・伊藤 哲男 $2 \cdot$ 八木 弘 3 ・水野 希典 4 ・前田 洸樹 5 ・進士 正人 6 \\ 1 正会員 株式会社高速道路総合研究所 道路研究部（†194-8508 東京都町田市忠生 1-4-1） \\ E-mail: s.kaise.aa@ri-nexco.co.jp \\ 2 正会員 株式会社高速道路総合研究所 道路研究部（†194-8508 東京都町田市忠生 1-4-1） \\ E-mail: t.ito.ak@ri-nexco.co.jp \\ 3 正会員 中日本高速道路株式会社 技術支援部（干460-0003 愛知県名古屋市中区錦 2-18-19） \\ E-mail: h.yagi.aa@c-nexco.co.jp \\ 4 正会員 西日本高速道路株式会社 関西支社 建設事業部（干194-8508 大阪府茨木市岩倉町 1-13） \\ E-mail: m.mizuno.aa@w-nexco.co.jp \\ 5 正会員 パシフィックコンサルタンツ株式会社 トンネル部（†101-8462 東京都千代田区神田錦町 3-22） \\ E-mail: kouki.maeda@tk.pacific.co.jp \\ 6 正会員山口大学大学院教授＼cjkstart創成科学研究科（干755-8611 山口県宇部市常盤台 2-16-1） \\ E-mail: shinji@yamaguchi-u.ac.jp
}

高速道路会社（NEXCO）の覆工詳細点検システムは，覆工点検画像取得システムによる覆工展開画像 撮影記録から机上調查を実施し, 重点点検個所を抽出する机上点検と技術者による詳細実施点検の組合せ で構成されている，両点検とも覆工ひびわれ指数(TCI)に基づく外力およびはく落に関連する評価点と特 記項目を組合せて評価を行っている。本報告では，高速道路の覆工詳細点検の高精度化および効率化を目 的に, NEXCO が保有する 85000 スパン以上の点検データ分析を行った. 分析の結果, 建設工法の違いに より覆工健全度評価に異なる傾向を有することがわかった. また, 机上点検と詳細実施点検との比較によ り, 点検システムの実用性は高いが, 今後, 更なる高精度化と効率化のため特記事項の照査や変状の進行 性の把握等を検討する必要性が明らかとなった。

Key Words : tunnel lining concrete, Tunnel-lining Crack Index, health monitoring method, threshold

\section{1. はじめに}

東日本・中日本・西日本高速道路株式会社（以下 “NEXCO”という）が管理する高速道路トンネルは, その前身の日本道路公団が名神高速道路 栗東〜尼崎間 の管理を開始した昭和 38 年から平成 28 年 3 月末現在で 1808 本, 総延長 $1705 \mathrm{~km}$ がその対象である. これらのト ンネルを網羅的にかつ経済的に管理・点検をおこなう統 一的な点検手法の確立が喫緊の課題となっている.

そのため, 平成 24 年より, NEXCO が管理するトンネ ルの詳細点検は，供用前に実施される初期点検以降は， 図-1 に示す覆工画像撮影記録に基づき表-1 に示す覆工 の健全度ランクによりスパンごとに評価したうえで，問 題があると判断されるスパンを抽出する机上点検（以下

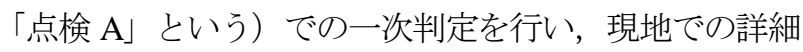

点検（以下「点検 B」という」）を行う点検システムを 標準的に導入し, 平成 27 年からは道路法の改訂により 全線の近接目視と合わせて詳細点検を実施している.こ れら点検手法は従前（点検 B のみ実施）と比較して,

表-1＼cjkstart健全度ランクの標準（トンネル） 1)

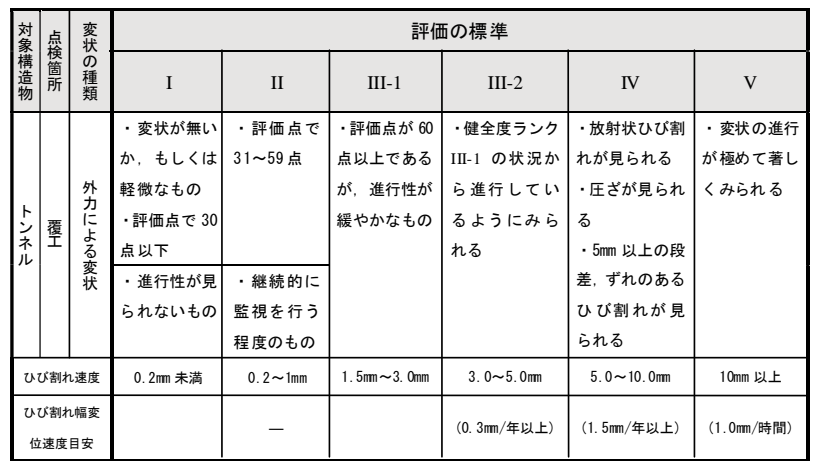


点検 $\mathrm{B}$ 実施箇所の抽出を前提とする試算では，点検日 数で約 $20 \%$, 点検費用で約 $6 \%$ の削減が見込まれる.

本報告は， NEXCOが管理する 85000 スパンを超える トンネル覆工点検結果のデータを分析し，(1)覆工画像 撮影により健全性を診断している点検 A と現地におけ る実施点検である点検 B の比較分析，(2)健全性評価の 基本となる 外力評価点およびはく落評価点と健全度ラ ンクの関連性分析，(3)外力評価点およびはく落評価点 の閾值の検証を行ったものである. なお，外力評価点お よびはく落評価点とは，覆工ひびわれ指数 ${ }^{2)}$ (以下

「TCI（Tunnel-lining Crack Index）」という）を基礎に NEXCO が提案した覆工の健全度指標である.

\section{2. 既往のトンネル覆工点検手法}

トンネル覆工の点検手法は，鉄道系，道路系，水路な どの電力系など，トンネルを維持・管理する組織により 管理手法が異なる．主に高速道路を管理する NEXCO の トンネルの点検手順は，図-1 に概述するようにレーザ 一, CCD カメラ, ラインセンサーカメラ等による覆工 表面画像取得システムによる覆工画像撮影記録を基にし ている．覆工画像撮影記録から問題があると判断される 個所およびスパンを表-2，3 に示す特記事項および閾值 を用いて重点点検個所として抽出する点検 A, そして, 点検 $\mathrm{A}$ の判定結果に基づき, 現地での近接目視，打音 点検等の重点点検を実施する点検 $\mathrm{B}$ により構成されて いる．他機関の詳細点検においても，覆工画像撮影技術

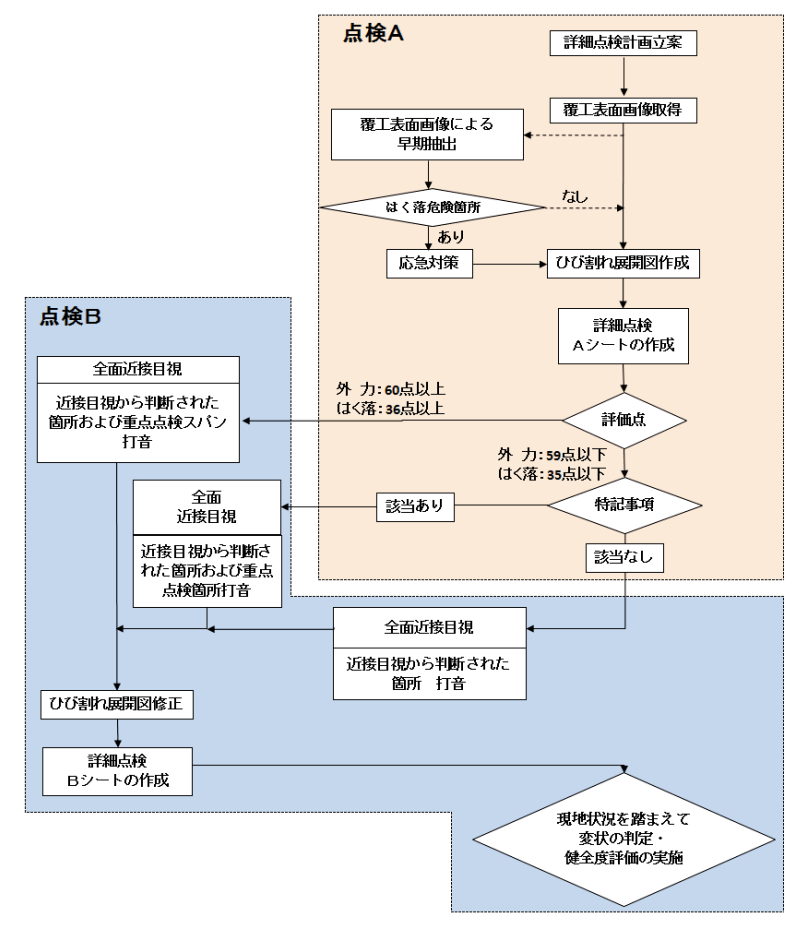

図-1 トンネル詳細点検の流れ ${ }^{3)}$
として NEXCO と同様の覆工画像取得システムの一部が 導入されている他，鉄道会社などでは赤外線による覆工 表面のうき・はく離の抽出技術の活用検討 のがなされて いる.しかし，当初から技術者による近接目視および打 音点検の夕で覆工点検が実施されている機関も多いが, どの機関とも限られた予算内で効率的に多数のトンネル を統一的に管理するには，効率的な維持管理計画を立て る必要に迫られている.

NEXCO が管理するトンネルは，トンネル工法が鋼製 支保工と矢板を主たる支保部材とする矢板工法から，吹 付けコンクリート，ロックボルト，鋼製支保工等を主な 支保部材とする山岳トンネル工法に変化している上に, その判定方法も他機関と同様に定性的な表現 ${ }^{77}$ が多く, 技術者の経験的判断によるところが大きかった．そこで， より効率的な定量的健全度評価を目指して NEXCO は平 成 24 年から覆工点検手法を変更した. 以降, NEXCO が 提案している覆工点検手法の概略とそこで用いられてい るひびわれ指数(TCI)について述べる.

表-2 外力評価点・はく落評価点の閾值 ${ }^{10,4,5)}$

\begin{tabular}{|c|c|}
\hline 閾値設定項目 & 閾値の評価点内容 \\
\hline $\begin{array}{l}\text { 覆エ画像判 } \\
\text { 定より覆エ } \\
\text { 全面の入念 } \\
\text { な打音実施 } \\
\text { スパン抽出 }\end{array}$ & $\begin{array}{l}\text { 「入念な覆工全面の打音実施スパン対象条件」 } \\
\text { ·外力評価点「 } 60 \text { 点以上」 } \\
\text { •はく落評価点「 } 36 \text { 点以上」のいずれかのスパン } \\
\text { ※現在, 覆工全面において近接目視かつ打音を基本 } \\
\text { としているが, 入念に覆工全面の打音を実施するス } \\
\text { パン抽出に活用 }\end{array}$ \\
\hline \multirow{3}{*}{$\begin{array}{l}\text { 健全度ラン } \\
\text { ク評価の目 } \\
\text { 安 }\end{array}$} & $\begin{array}{l}\text { 健全度ランク I : 変状がない，もしくは軽微なもの } \\
\text { 健全度ランク Iの該当スパン : 外力評価点「 } 30 \text { 点以 } \\
\text { 下」 }\end{array}$ \\
\hline & $\begin{array}{l}\text { 健全度ランク II : 変状があるが, 現状は継続的に監 } \\
\text { 視を行う必要があるもの } \\
\text { 健全度ランク II の該当スパン：外力評価点「31 点 } \\
\text { ～59 点」 }\end{array}$ \\
\hline & $\begin{array}{l}\text { 健全度ランク III-1 : 変状はあるが, 進行が緩やか } \\
\text { 健全度ランク III-1 の該当スパン : 外力評価点「60 } \\
\text { 点以上」 } \\
\text { 健全度ランク III-2, IV, V の該当スパン : 外力評価 } \\
\text { 点「60 点以上」で変状が進行しているもので } \mathrm{IV}, \\
\mathrm{V} \text { につては, 外力評価点「 } 60 \text { 点以上」「変状が } \\
\text { 進行」+ } \alpha \text { の条件 }\end{array}$ \\
\hline
\end{tabular}

表-3 特記事項 4 ,5)

特記事項（重点点検箇所）

・ひび割れ幅 $2 \mathrm{~mm}$ 程度のひび割れが連続して $3 \mathrm{~m}$ 以上ある.

• ひび割れ幅 $3 \mathrm{~m}$ 程度以上のひび割れがある.

·打継ぎ目部に三日月型のひび割れがある.

・ 添架物（ジェットファン, 標識等）のアンカ一部およびそ

の周辺に放射状のひび割れがある.

・モルタル系の補修材による既対策箇所がある.

·豆板, ジャンカ等があり, 浮き・はく離の危険性がある.

·構造上問題があると判断されるひび割れがある.

- 健全度ランク III-1，III-2, IV, V に対し, 前回点検時から補 修・補強が実施されていない. 


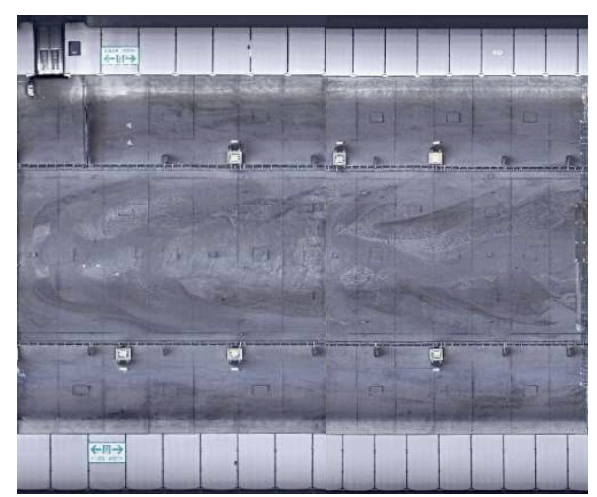

図-2 覆工画像撮影例

点検 A
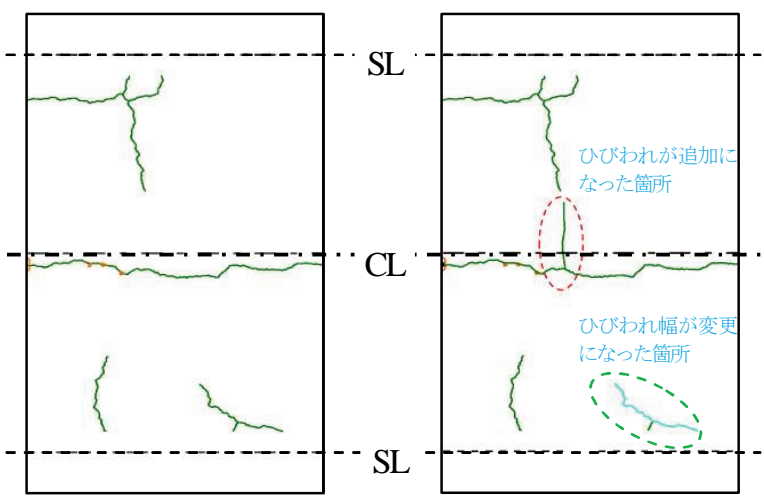

図-3＼cjkstart点検 A・Bによるひびわれ展開図例

\section{(1) 点検 A}

覆工画像撮影記録を基にひびわれ展開困を作成し，問 題個所および重点点検スパンを抽出する机上点検を「点 検 $\mathrm{A} 」 と$ 呼ぶ. この点検では，覆工画像取得の良否がそ の後の評価に大きく影響を与えるものの，高速道路利用 者のサービスレベルを低下させないことを最重要事項と し，画像取得に当たっては計測車両の走行速度は原則 $50 \mathrm{~km} / \mathrm{h}$ 以上で実施している．また，覆工画像撮影記録 の精度は，作業効率やひびわれなどの認識精度を考慮し， $0.5 \mathrm{~mm}$ 程度のひびわれ幅を認識できるものを，撮影に用 いる機器の仕様について具体に定め適用している. 図-2 に覆工画像撮影例，図-3 に点検 $\mathrm{A}$ および $\mathrm{B}$ により作成 したひびわれ展開図の例を示す。覆工画像撮影後に，図 -4 に示す詳細点検 A シート（以下「A シート」という） に，トンネル名，延長，路線名等の「1. トンネル諸元 等」，緊急補修・対策工検討を要する項目の「2. 特記事 項」，ひびわれやエフロレッセンス，漏水の状況の「3. データシート」にそれぞれ記入し原則として，覆工コン クリートの一打設長であるスパン単位で評価を行う。

\section{(2) 点検 B}

高所作業車等により技術者が，全線の近接目視かつ打 音点検を実施する詳細点検を「点検 $\mathrm{B}\rfloor$ と呼ぶ.この点 検時に，覆工画像撮影では捉え切れない，ひびわれが顕 在化してない浮き，排気ガスの煤煙により判別が難しい

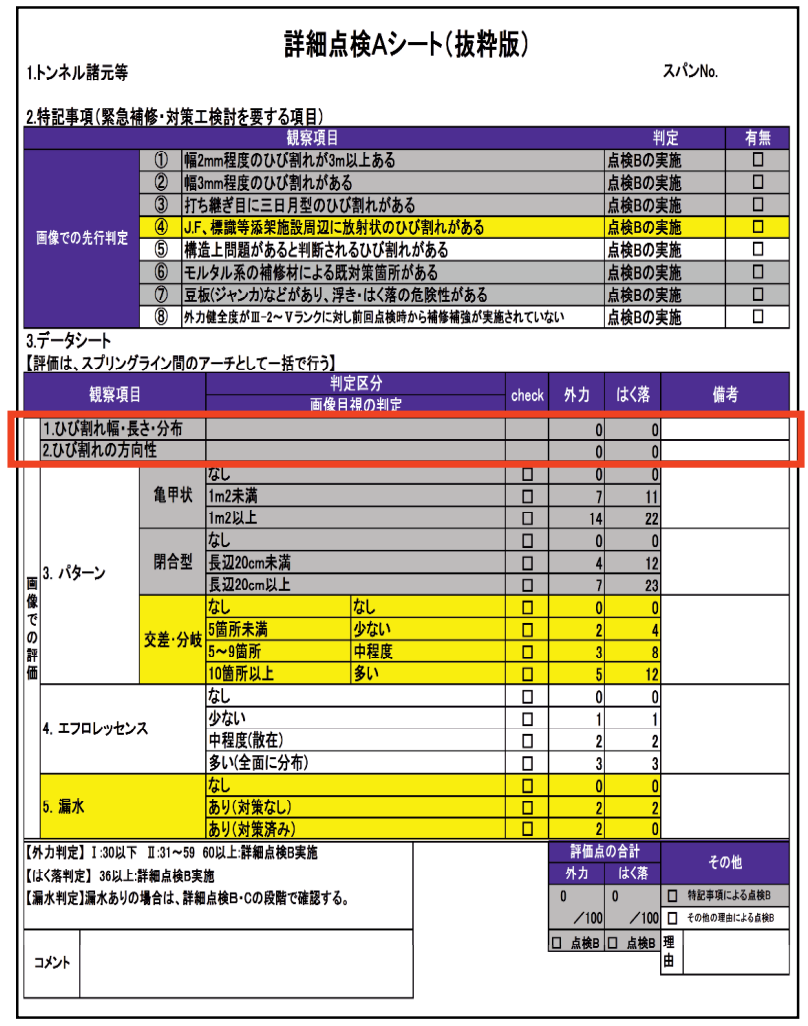

図-4 詳細点検 Aシート様式

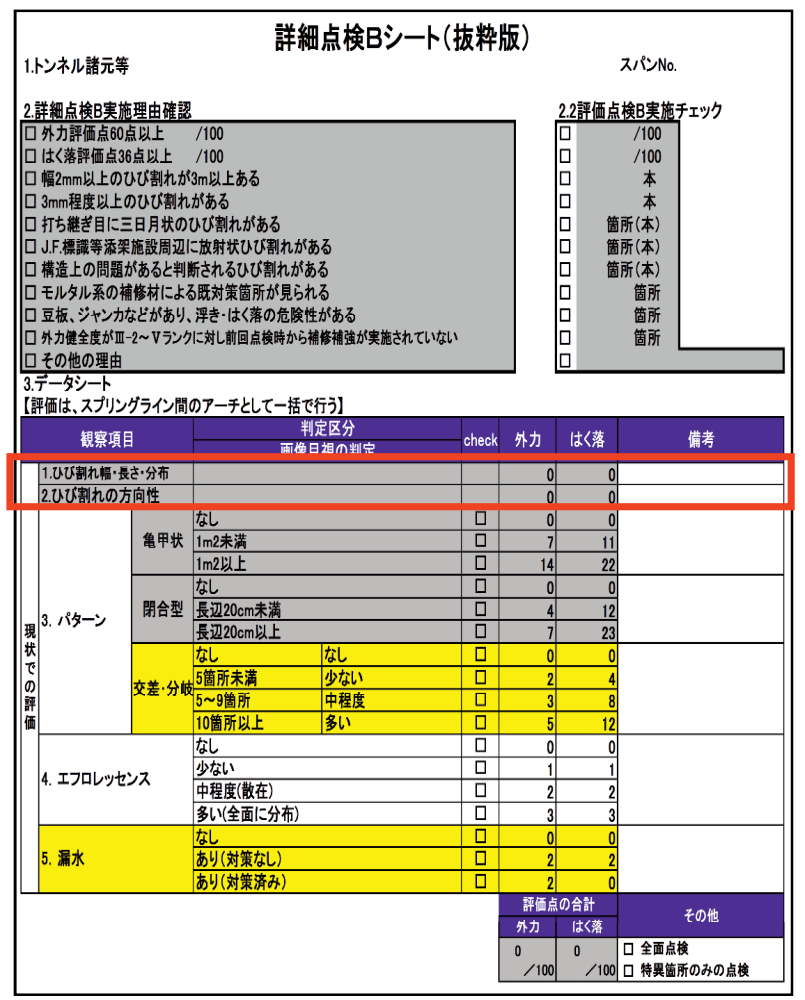

図-5 詳細点検 B シート様式

いひびわれ等の把握や，点検 $\mathrm{A}$ での判定結果より，重 点点検スパン並びに重点点検個所として抽出された場所 については，とくに入念に打音点検を実施することとし ている. 具体的には点検に合わせて図-5 に示す詳細点 検 B シート（以下「Bシート」という）に，A シートと 同様に，「1. トンネル諸元等」，「3. データシート」と， 
特記事項に準じた「2. 詳細点検 B 実施理由確認」を記 入しスパン単位で評価を行う。また，図-4，5の赤枠部 分「1.ひびわれ幅・長さ・分布」，「2.ひびわれの方向 性」の 2 項目のひびわれの量の評価は, 次節で述べる TCIを用いて，共通の評価をしている.

\section{(3) $\mathrm{TCl}$}

NEXCO では，これまで述べた二段階の覆工点検の主 要要素として, 覆工の健全度を数值的に評価する指標と して TCIを導入している. TCIの考え方を以下に示す.

TCI は，覆工に発生するひびわれを定量的に評価する ために, ひびわれの密度や方向, 幅を総括的に定量化す る指標であるクラックテンソルを援用し，スパン毎の覆 工の定量的健全性評価法として提案された指標である.

TCI の基礎式 ${ }^{8)}$ を式(1)に示寸とともに，その概念図を図6 に示寸. 式で示寸 $F_{11}, F_{22}$ は, それぞれ TCI の縦断成 分，横断成分を示寸ものである. このテンソルの一次不 変量 $F_{0}$ を「TCI と呼び, 数量的トンネル覆エコンクリ 一トの劣化の指標として, 縦断・横断成分の和 $\left(F_{0}=F_{11}+\right.$ $\left.F_{22}\right)$ から算出する. それに対し， $F_{12}$ は TCI の対角項成分 であり，ひびわれの斜め方向成分の多さを表寸ものであ る.

$$
F_{i j}=\frac{1}{A} \sum_{k=1}^{n}\left(t^{(k)}\right)^{\alpha}\left(l^{(k)}\right)^{\beta} \cos \theta_{i}^{(k)} \cos \theta_{j}^{(k)}
$$

$A:$ 覆工コンクリートの面積 $(A=L s \times L a)$

$L s:$ 覆工コンクリートの縦断延長（通常はスパン長）

$L a:$ 覆工コンクリートの横断延長

$n:$ びわれの本数

$l^{(k)}:$ ひびわれkの長さ

$t^{(k)}:$ ひびわれkの幅

$\theta_{i}{ }^{(k)}:$ ひびわれ $k$ の法線ベクトルがx軸とな寸角度

$\theta_{j}^{(k)}:$ ひびわれ $k$ の法線べクトルが $x$ 軸とな寸角度

$\alpha$ :ひびわれ幅の重み付けに関する係数

$\beta:$ ひびわれ長さの重み付けに関する係数

$F_{0}:$ TCI $の$ 一次不変量

$F_{11}:$ TCI $の$ 縦断方向成分

$F_{22}:$ TCI $の$ 横断方向成分

$F_{12}=F_{21}: \mathrm{TCI}$ の斜め方向成分

\section{3. 覆工点検結果の整理}

(1) 対象トンネル

NEXCO では昭和 58 年から山岳トンネル工法が標準と なった. それ以前は, 矢板工法での施工を行っており他 の機関のようなレンガ積みやブロック積みのトンネルは

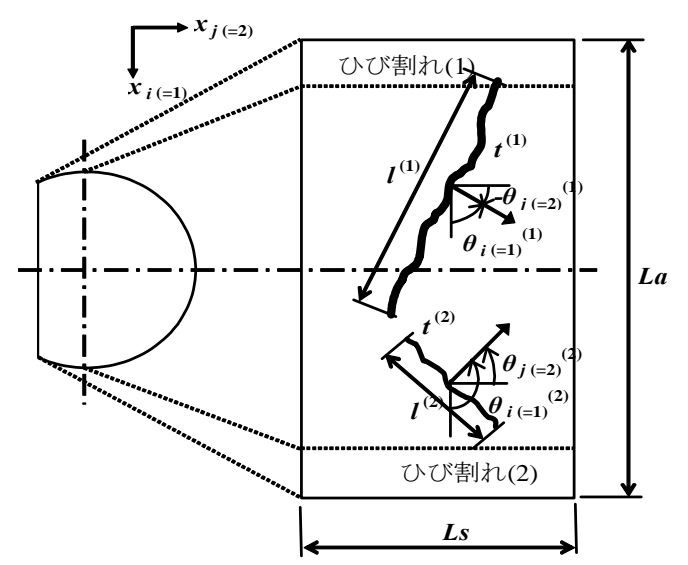

図-6 TCI の概念図 ${ }^{8)}$

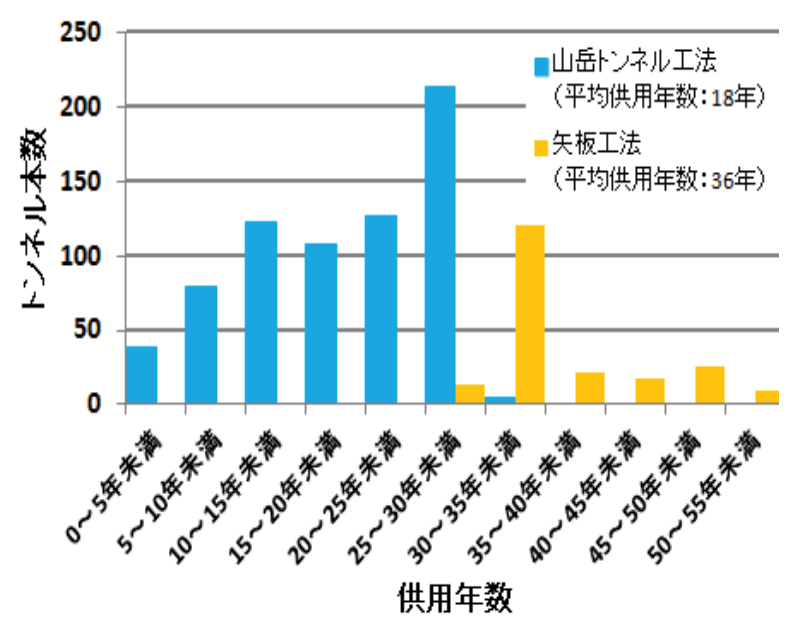

図-7 工法別の供用年数

存在しない. 本研究で収集し対象とした覆工点検データ は, トンネル総延長が 856 953m であり, 掘削工法別に は山岳トンネル工法が 80\% (684 976m) ，矢板工法が 20\%（171977m）のデータである.

工法別のスパン数は, 総スパン 85303 に対し, 山岳卜 ンネル工法（68 092 スパン）が 80\%，矢板工法（17 211

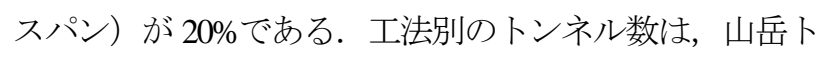
ンネル工法（692 本）が 77\%, 矢板工法 (207 本) が $23 \%$ あ゙り, 延長, スパン数, トンネル数の工法別の割 合はほぼ同等である.また, 図-7 に工法別の供用年数 の分布を示す. 平均供用年数は, 山岳トンネル工法が約 18 年, 矢板工法が約 36 年と, 矢板工法は施工時期が古 いため供用年数が 18 年長い結果となった. これらデー 夕を工法別を基本として分析を行う。

\section{(2) 外力評価点およびはく落評価点}

NEXCO では，山田らの TCI の活用研究 ${ }^{8}$ に基づき TCI を直接用いるのではなく覆工に発生しているひびわれが 
外力の作用を受けているかの判定をおこなう「外力評価 点」および覆工のはく落につながる可能性のあるひびわ れの判定をおこなう「はく落評価点」を，TCI から以下 のように，式(2)，(3)を用いて換算して図-4，5 の点検シ 一トの「1.ひびわれの幅・長さ・分布」に用いている.

外力評価点 $y_{1}$

$$
y_{1}=\frac{58 \times x \times 10^{5}}{\left(x \times 10^{5}+10\right)}
$$

はく落評価点 $y_{2}$

$$
\begin{aligned}
& y_{2}=\frac{32 \times x \times 10^{5}}{\left(x \times 10^{5}+13\right)} \\
& \text { ここで, } \quad x: T C I
\end{aligned}
$$

また，図-4，5 の点検シートの「2.ひびわれの方向性」 に関する判定 ${ }^{81}$ は縦断・斜め卓越型, 縦横断拮抗型, 横 断卓越型として式(4)の值から表-4 のような外力評価点 およびはく落評価点を決定している.

ひびわれ方向性 $z$

$$
z=\frac{F_{22}}{F_{0}}
$$

表-4 ひびわれの方向性に対する評価点

\begin{tabular}{|c|c|c|c|}
\hline$z$ & $\begin{array}{c}\text { 外力評価点 } \\
y_{1}\end{array}$ & $\begin{array}{c}\text { はく落評価点 } \\
y_{2}\end{array}$ & 備 考 \\
\hline $0 \leqq Z<0.3$ & 11 & 6 & 継断·斜め卓越型 \\
\hline $0.3 \leqq Z<0.7$ & 7 & 4 & 繸横断拮抗型 \\
\hline $0.7 \leqq Z \leqq 1.0$ & 4 & 2 & 横断卓越型 \\
\hline
\end{tabular}

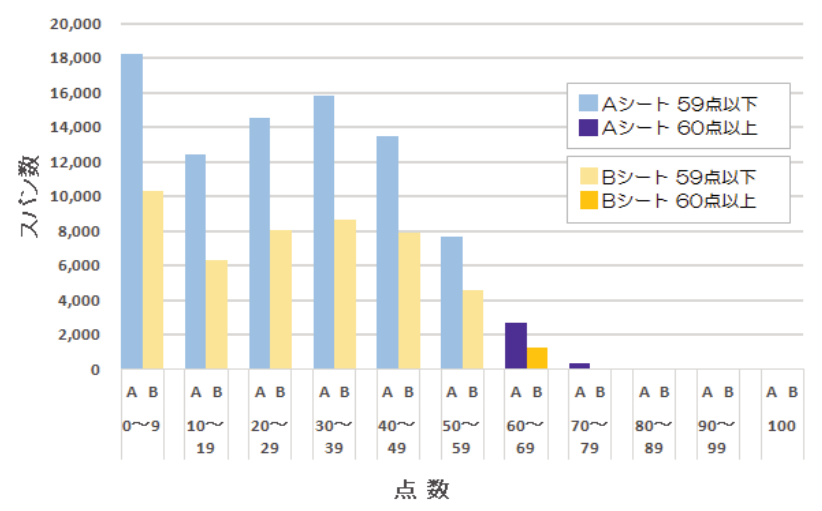

図-8 A・B シート外力評価点（総スパン内訳）
表-2 に示すように, 外力評価点が 60 点以上，もしく は, はく落評価点が 36 点以上の場合に詳細点検に位置 づけられる点検 $\mathrm{B}$ を行うなかで近接目視および打音点 検を重点的に実施することにしている.

点検 B を実施する要因を分析を行うために，3.(1)で収 集したデータから，点検 A を実施した 85303 スパン, 点検 B まで実施した 47261 スパンからそれぞれの外力 およびはく落の評価点を算出した内訳を図-8，9 に示寸. 点検 $\mathrm{A}$ において, 外力評洒点 60 点以上のスパンは 3061 スパン, はく落評価点 36 点以上のスパンは 10127 スパンであるが，実際は 47261 スパンを詳細点検として 実施しており，閾值以上のスパン数より，約 4 倍程度の スパンの詳細点検を行っている．これは，評価点が閾值 未満のスパンであっても，表-3 に示寸項目の特記事項 に該当寸場合には点検 B を行うためで, 現状では点検 Aにおける閾值以上のスパン数よりも，点検 $\mathrm{B}$ を行って いるスパン数のほうが圧倒的に多い，また，閾值未満お よび特記事項がないスパンにおいても，近傍のスパンで 点検 $\mathrm{B}$ を行った場合は合わせて点検を行う事例も十分 想定できる.

点検 B を実施した 47261 スパンについて点検 A シー 卜との評価項目でベン図で分類すると，図-10 のように 分類される. 近傍のスパンということで実施している 24819 スパンを除く, 22442 スパンのうち特記事項の記 載があるものが 20212 スパンであり全体の約 90\%を占 めている. また, 特記事項の内訳を整理すると, 複数の 項目にチェックをしている状況で表-5 の内訳となり, (7)の「豆板（ジャンカ）などがあり, 浮き・はく落の 危険性がある」の項目が 11114 スパン，(3)の「打ち継ぎ 目に三日月型のひびわれがある」の項目が 5920 スパン と，特記事項の記載があるスパンの約 $40 \%$ ，約 $21 \%$ と 高い割合を占めており，第三者被害に直結しやすい特記 事項のチェック率が高い結果となった.

このことから, 今後, より効率的に点検 B を実施す るためには, 閾值の設定の適正化とともに，特記事項の 照査, 整理も合わせて重要であることがわかった.

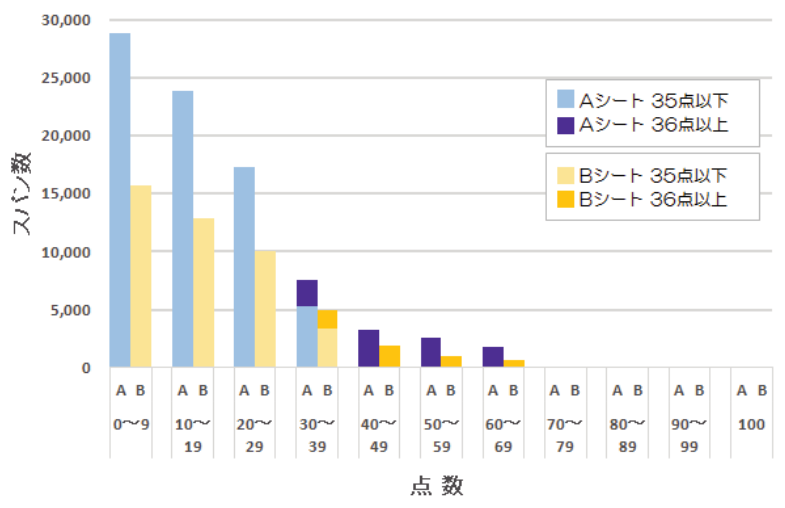

図-9 A・B シートはく落評価点（総スパン内訳） 


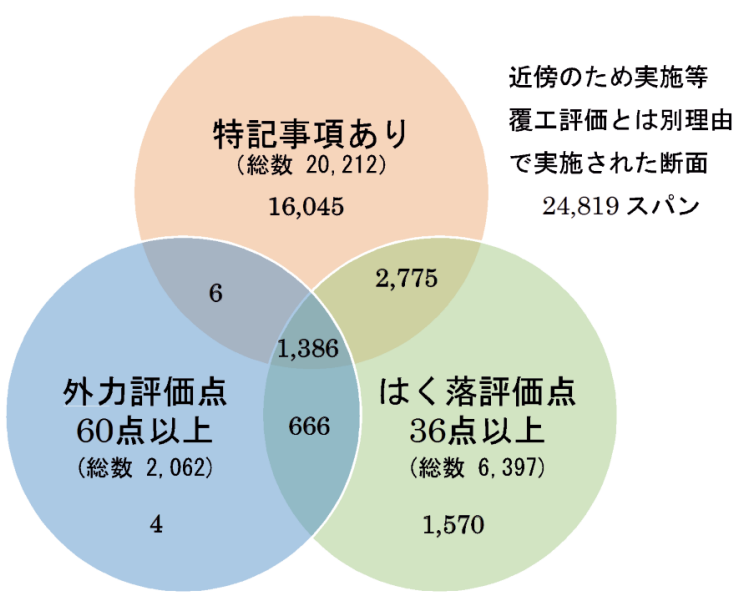

図-10 詳細点検 $\mathrm{B}$ の実施内訳

表-5 特記事項の内訳

\begin{tabular}{|c|c|c|c|}
\hline 項目 & 評価内容 & スパン数 & チェツク率(\%) \\
\hline$(1)$ & 幅2mm程度のひび割れが3m以上ある & 2,629 & 9.5 \\
\hline (2) & 幅3mm程度のひび割れがある & 565 & 2.0 \\
\hline (3) & 打ち継ぎ目に三日月型のひび割れがある & 5,920 & 21.4 \\
\hline (4) & $\begin{array}{l}\text { J.F, 標識等添架施設周辺に放射状のひび } \\
\text { 割れがある }\end{array}$ & 834 & 3.0 \\
\hline (5) & $\begin{array}{l}\text { 構造上問題があると判断されるひび割れ } \\
\text { がある }\end{array}$ & 2,249 & 8.1 \\
\hline (6) & $\begin{array}{l}\text { モルタル系の補修材による既対策箇所が } \\
\text { ある }\end{array}$ & 4,202 & 15.2 \\
\hline (7) & $\begin{array}{l}\text { 豆板(ジャンカ)などがあり, 浮き・はく落の } \\
\text { 危険性がある }\end{array}$ & 11,114 & 40.1 \\
\hline (8) & $\begin{array}{l}\text { 外力健全度がIII-2 Vランクに対し前回点 } \\
\text { 検時から補修補強が実施されていない } \\
\end{array}$ & 204 & 0.7 \\
\hline \multicolumn{2}{|c|}{ 特記事項記載スパン数の合計※) } & 27,717 & 100.0 \\
\hline
\end{tabular}

※複数の項目にチェックしているスパンがあるため合計は20,212にならない

\section{4. 評価点および健全度ランクの分析}

\section{(1) 点検 $A, B$ の評価点のずれ}

図-4，5 で示すように，A，B シートの各評価点項目 は，TCI で評価される「1. ひびわれ幅・長さ・分布」，

「2.ひびわれ方向性」と，シートの配点により評価され る「3.ひびわれのパターン（亀甲状，閉合，交差・分 岐）」，「4. エフロレッセンス（量）」，「5. 漏水 (量)」の5 項目で算出される.

机上点検である点検 $\mathrm{A}$ と, 詳細点検である点検 $\mathrm{B}$ の 評価点の関係を分析するため, 横軸を A シートの評価 点, 縦軸を $\mathrm{B}$ シートの評価点とし, 外力評価点とはく 落評価点について工法別にその傾向を分析した. データ は，Aシートかつ B シートが存在する全スパン 47261 ス パン（山岳トンネル工法 354 本 37 306, 矢板工法 167 本 9955）である. 図-11，12，14，15 の破線（黒）は傾

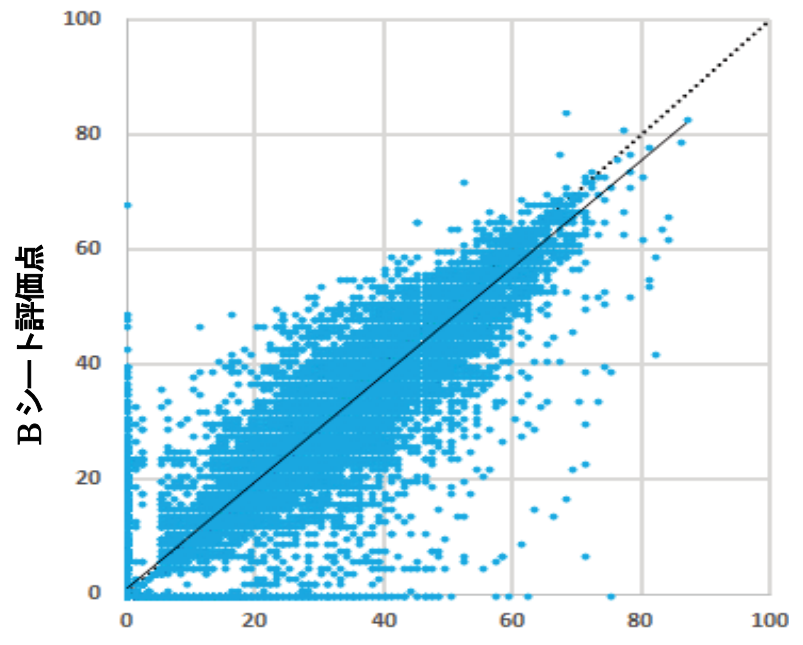

A シート評価点

図-11 外力評価点の分布 (山岳トンネル工法)

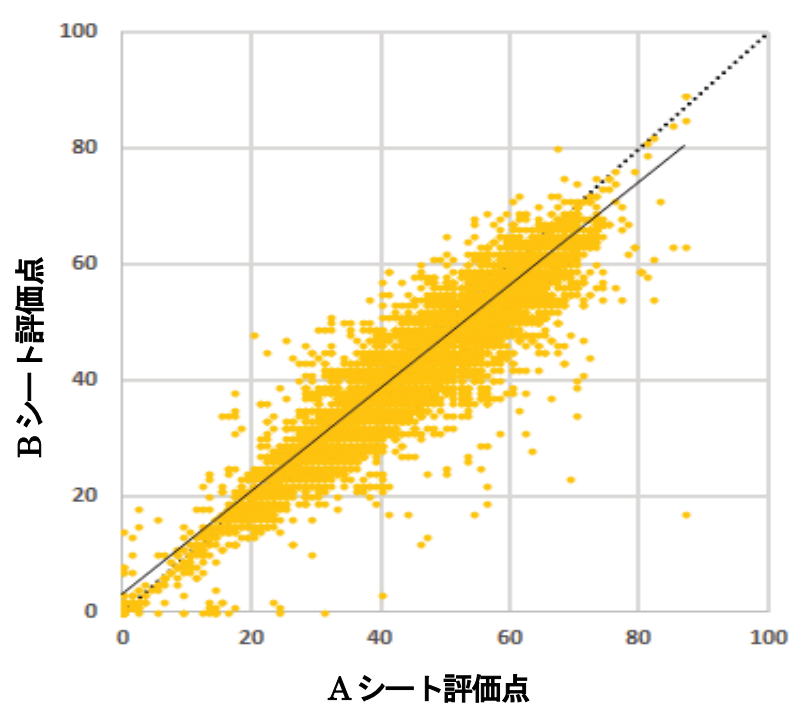

図-12 外力評価点の分布 (矢板工法)

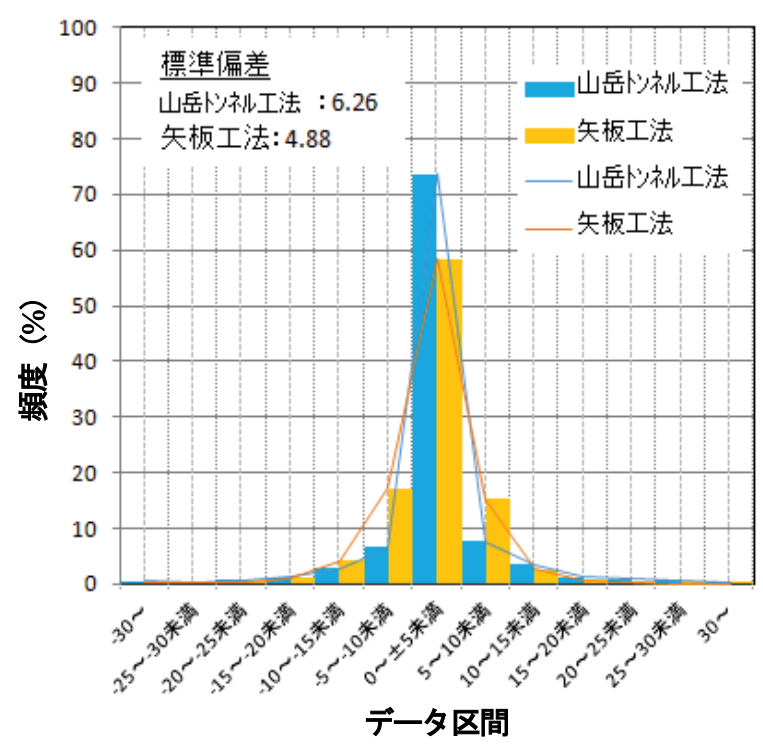

図-13 外力評価点の両シートの差分の頻度分布 (山岳トンネル工法・矢板工法) 
きが 1 の直線であり，この直線付近にプロットされたス パンは, 点検 $\mathrm{A}$ と点検 $\mathrm{B}$ における評価にずれがないこ とを表している. また, グラフ中の実線（黒）は, 要素 の回帰直線である.

\section{a) 外力評価点}

図-11，12 にトンネル施工法別の外力評価点の分析結 果を示す.工法別に見ると点検 A と点検 B の外力評価 点の差は, 山岳トンネル工法が大きい傾向が見て取れる. そこで, 点検 $\mathrm{B}$ の評価点数から点検 $\mathrm{A}$ の評価点を引い た差分を算出し，その頻度分布を図-13 に示寸．この図 からわかるように, 外力評価点の差分の標準偏差は山岳 トンネル工法が 6.26 で, 矢板工法が 4.88 と山岳トンネ ル工法が矢板工法に比べ大きく, 点検 $\mathrm{A}$ と点検 $\mathrm{B}$ の評 価点にばらつきがあることがわかる，とくに，山岳トン ネル工法は, 点数が低い側でその差が大きい傾向を示す. これは, 山岳トンネル工法は矢板工法に比較してひびわ れ幅およびその長さが全体に小さく, 評価点が小さい場 合は，とくにひびわれ幅が小さいと考えられるため，こ のことが工法の差に表れたと考えられる.これは，図14 に示寸工法別の TCI の累積割合分布比較においても, 山岳トンネル工法では，0.01×10 $0^{-5}$ 以下（ほとんどひびわ れがない状態）が全体の約 20\%，1.0×10 以下が約 40\% であるのに対して，矢板工法は $1.0 \times 10^{-5} \sim 50.0 \times 10^{-5}$ が 90\%以上を占めており, 山岳トンネル工法は矢板工法と 比較して TCIが小さく, ひびわれ損傷程度が小さいこと を評価点以外でも示しているものと考えられる. 寸なわ ち, 覆工画像のひびわれの読み取りに関する精度に起因 するものと推定される.

\section{b) はく落評価点}

図-15，16 にはく落評価点の分析結果を示寸.工法別 に見ると，外力評価点とは逆に矢板工法の方が点検 A と点検 B のはく落評価点の差が大きい傾向を示す. 前 節と同様それぞれの点検結果の差分の標準偏差を図-17 に示寸，標準偏差は山岳トンネル工法が 6.10 で，矢板 工法が 8.27 と矢板工法が山岳トンネル工法に比べばら つきが大きい.

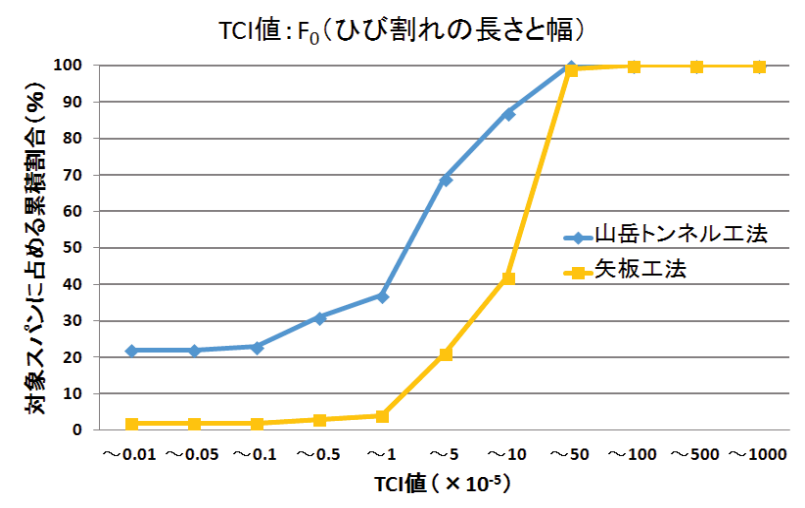

図-14 TCIのヒストグラム（山岳トンネル工法・矢板工法）

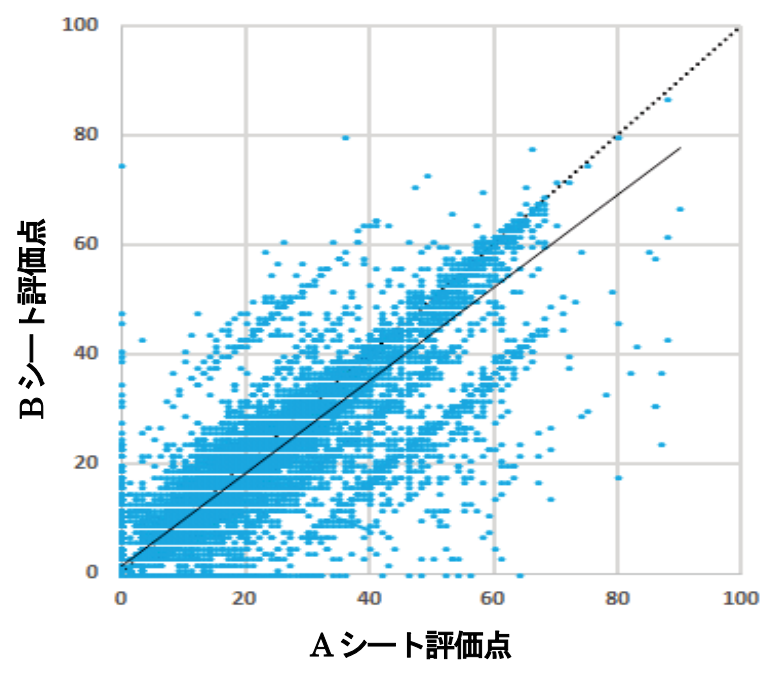

図-15 はく落評価点の分布（山岳トンネル工法）

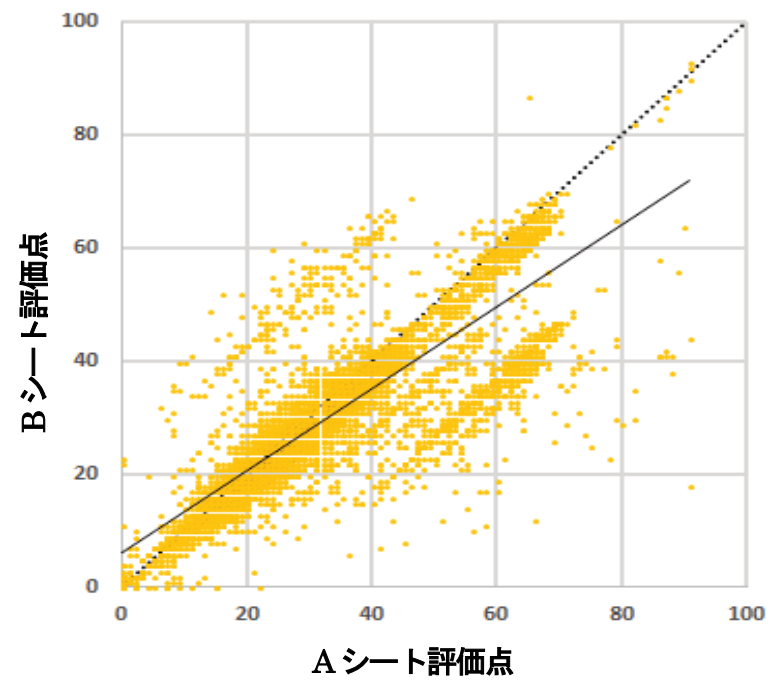

図-16 はく落評価点の分布（矢板工法）

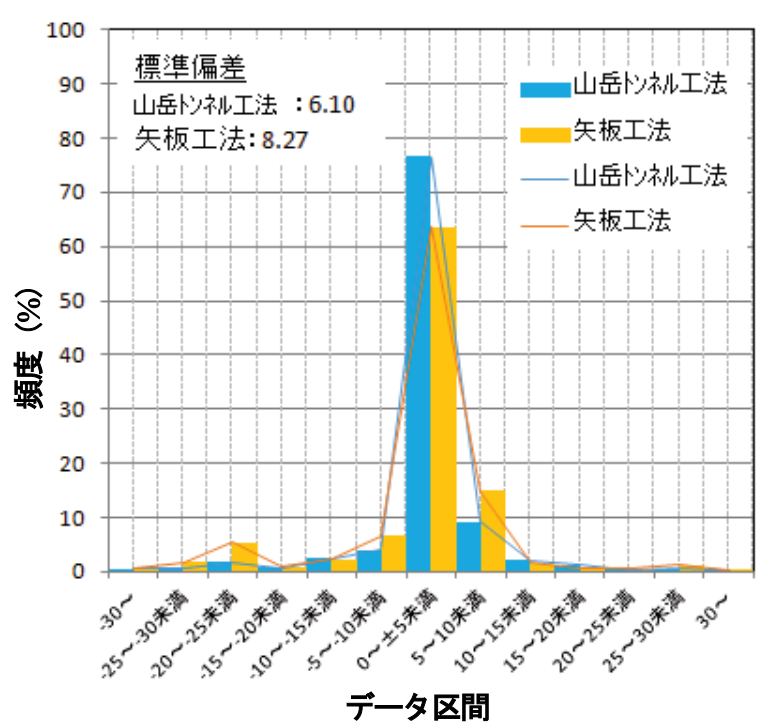

図-17 はく落評価点の両シートの差分の頻度分布 (山岳トンネル工法・矢板工法) 


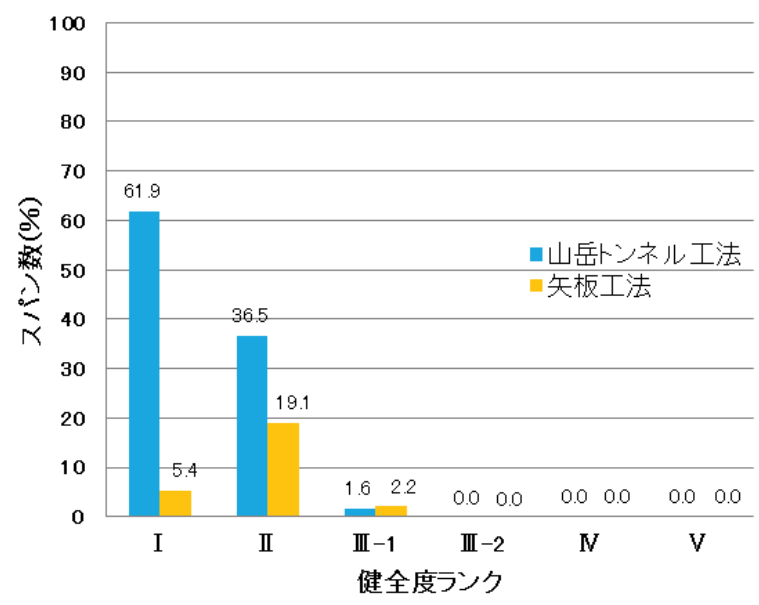

図-18 健全度ランクの分布（山岳トンネル工法・矢板工法）

また, 図-13 と比較して, 矢板工法でははく落評価点 の標準偏差が 8.27 に対して外力評価点のそれが 4.88 と 評価点のばらつきが大きい．これは 5.(3)b)「はく落評価 点におけるひびわれパターンの発生傾向」で後述する, はく落判定におけるひびわれ評価点の配点によるものと 推定され，ひびわれ幅およびその長さが山岳トンネル工 法に比較して大きいことが影響していると考えられる.

\section{c) A シートおよび B シート片方のみにしか点数が付か ない例}

図-11，12，15，16 の中で，A シートが 0 点であるも のの, B シートで点数がついている例が，外力評価点で 山岳トンネル工法 : 869 スパン, 矢板工法 : 37 スパンの 合計 906 スパン（全データ数の $1.92 \%$ ），はく落評価点 で山岳トンネル工法 : 873 スパン, 矢板工法 : 37 スパン の合計 910 スパン（全データ数の $1.93 \%$ ）存在する.こ れは, 覆工画像から展開図作成時にひびわれの確認漏れ の事例, 点検 $\mathrm{A}$ を実施後, 点検 $\mathrm{B}$ を実施するまでに新 規の変状発生により， B シートに点が付いている事例が 考えられる.

また，その逆で A シートで点数がついていたにもか かわらず， B シートが 0 点のものが，外力評価点の場合， 山岳トンネル工法 : 1124 スパン, 矢板工法 : 12 スパン の合計 1136 スパン（全データ数の $2.40 \%$ ），はく落評 価点では, 山岳トンネル工法 : 1130 スパン, 矢板工 法 : 13 スパンの合計 1143 スパン (全データ数の $2.42 \%$ ) 存在する.これは, 各シートを確認すると A シート作 成時に記載された変状が B シートでは確認されないも のがほとんどであった.

これら事象が発生した 4095 スパン (外力評価点 : 2 042 スパン，はく落評価点：2053 スパン）のうち，平成 25 年までに点検したスパンが 3897 スパンと全体の $95 \%$ を占めており, 点検時期が本点検システムを標準的に導 入した平成 24 年頃のものがほとんどであることから, 導入当初ということもあり覆工の縞模様の誤認等が要因
と考えられる．また，縞模様は山岳トンネル工法におい て全断面セントルを用いられてから顕著となっているこ とから，山岳トンネル工法において評価点 0 が多い理由 でもあると推測される。このようなスパンの発生は平成 26 年までであり, 画像判定導入から時間が経過した現 在はこのような事象は発生していない.

\section{(2) 健全度ランク}

工法別健全度ランクの分布の傾向を分析するため,

図-18 に現地にて健全度判定がされている山岳トンネル 工法 37302 スパン，矢板工法 9932 スパンに対して健 全度ランクの分布を示寸.

グラフの横軸は健全度ランク, 綐軸は対象スパンに 占める割合を示す。山岳トンネル工法は健全度 I のスパ ンの割合が最も多いのに対して，矢板工法は健全度 II が最も多くなっており，山岳トンネル工法に比較して健 全度ランクが全体に低い傾向にある。これは，施工法に よる違いの他に，図-7 に示寸ように施工後 30 年以上経 過し, 経年劣化等による变状の進行も劣化要因となって いると考えられる.

\section{5. 閾値の検討}

覆工詳細点検に使用している評価点の閾值は表-1，2 に示寸ように各種判定基準の目安にも使用されている. 今回，4.(1)と同椂に A シートかつ B シートが存在する 全スパン 47261 スパンに関して分析を行い，点検の実施 に際して影響がある，外力評価点と，はく落評価点の閾 值について検証を行った.

\section{（1）点検 $A$ の結果に基づく点検 $\mathrm{B}$ の実施状況}

表-2 に示すように，点検 A の評価が外力評価点では 60 点，はく落評価点では 36 点が，点検 $\mathrm{B}$ を実施し重点 的に打音点検を実施するスパンかどうかの閾值である. 閾値の設定の妥当性を検証するため，点検 $\mathrm{A}$ ではそれ ぞれの閾值を下回っていたものの，点検 $\mathrm{B}$ を行った結 果，閾值を上回った例を「捕捉漏孔」，それ以外を「捕 捉できた」として点検 B の結果を分析した. 図-19にそ の結果を示す.

図-19 中，1)の棒グラフに示寸特記事項のみにより B 点検を実施したスパンのうち, 外力評価点とはく落評価 点では 16045 スパン中 15513 スパンが捕捉でき捕捉率は 96.75\%であった．2)の棒グラフに示す近傍のため実施等 覆工評価とは別理由で実施されたスパンのうち, 外力評 価点とはく落評価点では 24819 スパン中 24107 スパン捕 捉でき捕捉率は 97.13\%であった。 3)は 2)の結果に特記 事項を考慮すると，その差分となる補足漏れの 712 スパ 


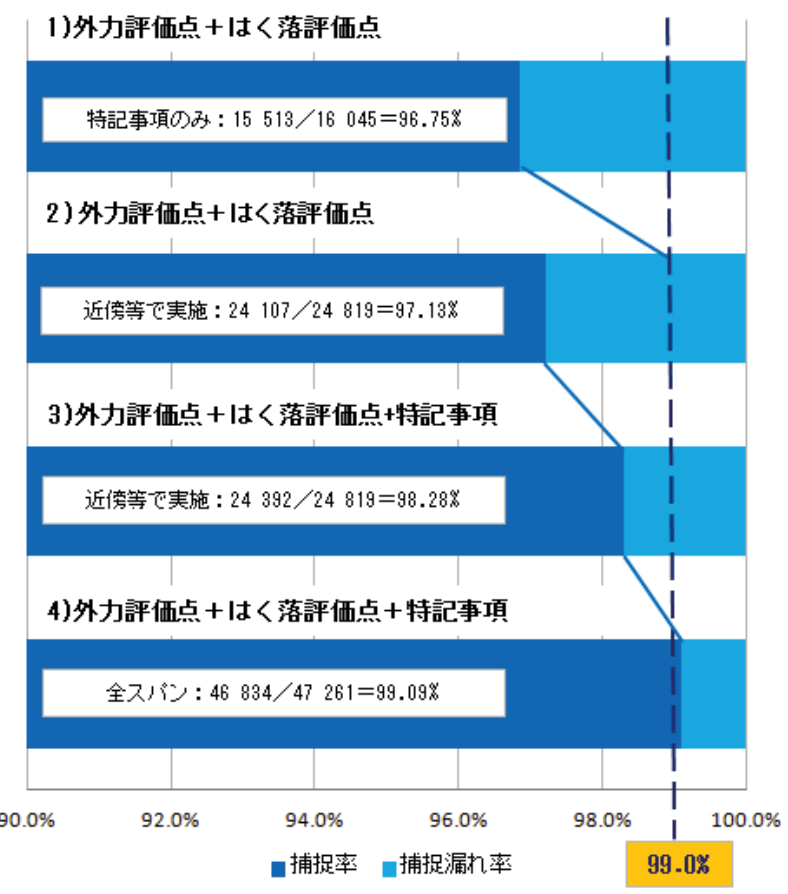

図-19 点検 Aによる捕捉率

ンのうち 285 スパンが捕捉でき，捕捉率は $98.28 \%$ であ った. 3)で捕捉漏れの 427 スパンを全スパンで比較する と捕捉率は 4)の棒グラフに示すように 99.09\%となった.

このことから，外力評価点およびはく落評価点で捕捉 出来ないスパンが存在すると考えられる, 特記事項のみ のスパンでは 96\%以上捕捉でき，近傍のため実施等覆 工評価とは別理由で実施されたスパンでは，97\%以上捕 捉し，特記事項による点検も含めると $98 \%$ 以上捕捉で きる.これは，全スパンを対象とすれば，99\%以上捕捉 できることから，点検 $\mathrm{B}$ を実施するための閾值として， 現状の数值は妥当であると判断している.

最終的に閾值で捕捉できなかったスパンのうち，点検 $\mathrm{B}$ 時に外力評価点の閾值を越えるものが 15 スパン，は く落評価点の閾值を超えるものが 142 スパンであった. 主な部分を占めるはく落評価点の閾值を越える 142 スパ ンを分析すると 142 スパンのうち A シートでは 130 スパ ンでひびわれパターン項目の「閉合型」が「なし」と判 定されているが，B シートでは「閉合型」が「なし」と 判定されたスパンが 52 スパンに減少しており，閉合型 のひびわれの判定が捕捉率に影響していると考えられる.

\section{（2）外力評価点の閾值の妥当性}

$\mathrm{NEXCO}$ では健全度ランク「IIII」以上のランクは, 外力評価点と合わせて変状の進行性を考慮し健全度ラン クを決定することにしており，変状の進行性が判断ポイ ントとなる．そのため，健全度ランク「IIII-1」〜「V」 と判定した覆工スパンが，閾值の 60 点以上と判定され たスパンであれば，補修が必要であるスパンを重点点検
個所として点検できたと考え，その時の閾值は妥当であ ると考えられる.

図-20 に健全度ランクと外力評価点の関係を示す.グ ラフは横軸が A シートによる外力評価点, 縦軸が B シ 一トによる外力評価点を示した上で，それぞれの覆工ス パンに対し判定された健全度ランクを色別で表現してい る.この図から，健全度ランクが「I」のスパンは B シ 一トの外力評価点が「0〜30 点」に, 健全度ランクが 「II」のスパンは外力評価点が「31〜59 点」に，健全度 ランクが「III-1」〜「IV」のスパンは外力評価点が「60 点以上」に，概ね分布している.

そこで，B シートに着目し，健全度ランクごとのスパ ン数の割合を図-21 に示す。この図から，「III-1」のス パンは, 1388 スパン中 $98.3 \%$ に当る 1302 スパンが,

「III-2」のスパンは，11 スパン中 6 スパンが，「IV」の スパンは，6スパン中 2 スパンが外力評価点 60 点以上に 分布している.

以上より，「III-1」〜「IV」のスパンで 60 点以上のス パンは 1405 スパン中 $93.2 \%$ に当たる 1310 スパンとなり 闇值の設定は妥当であったと判断している.しかし，変 状の進行状態の評価がより深刻な「III-2」，「IV」のス パンは全 1405 スパン中 17 スパンと極めて少ないものの, 60 点以上が，「III-2」が 11 スパン中 6 スパン (54.5\%)， $\lceil\mathrm{IV} 」 6$ スパン中 2 スパン $(33.3 \%)$ と 59 点以下のスパ ンが存在している.これは，対象スパン内に大きなひび われがあっても，TCI から算出される評価点は，ひびわ れ幅, 長さ, 密度, 分布が平準化されることから, 進行 性の判断が今後重要となることを意味している.

したがって，健全度判定を行う上で外力評価点の閾值 は妥当と判断できるものの，今後，精度向上のため，評 価点に変状の進行性を考慮した評価方法の検討が重要と 考えられる.

\section{(3) はく落評価点の閾値の妥当性}

はく落評価点の閾值の 36 点について，はく落評価点 の分布傾向および健全度ランクとはく落評価点の関係を 分析し，閾值の妥当性を検証する.

a) 健全度ランクとはく落評価点

覆工の健全度ランクは，外力評価点とひびわれの進行 性を考慮し決定されるため, 健全度ランクとはく落評価 点とは直接的な関係はない. しかし，外力評価点と同様 に健全度ランク「III-1」〜「V」が，はく落評価点の閾 值以上と判定されたスパンであれば補修が必要であるス パンを重点点検個所として点検でき，はく落評価点の閾 值として利用できると考えられる.

図-22 に，(1)外力評価点と同様のデータを用い健全度 ランクとはく落評価点の関係を示す.

これを見ると，健全度ランクが「I」のスパンは B シ 
一トのはく落評価点が「0３0 点」に，健全度ランクが

「II」のスパンははく落評価点が「15～60 点」に，健全 度ランクが「III-1」のスパンははく落評価点が「36 点以 上」に，概分布している.

図-23 に示す健全度ランクごとのはく落評価点による 捕捉率を見ると，「III-1」のスパンが 1388 スパン中 1 332 スパンが, 「III-2」のスパンは, 11 スパン中 6 スパ ンが，「IV」のスパンは，6 スパン中 2 スパンがはく落 評価点 36 点以上に分布している.

以上より，「III-1」〜「IV」のスパンで 36 点以上の

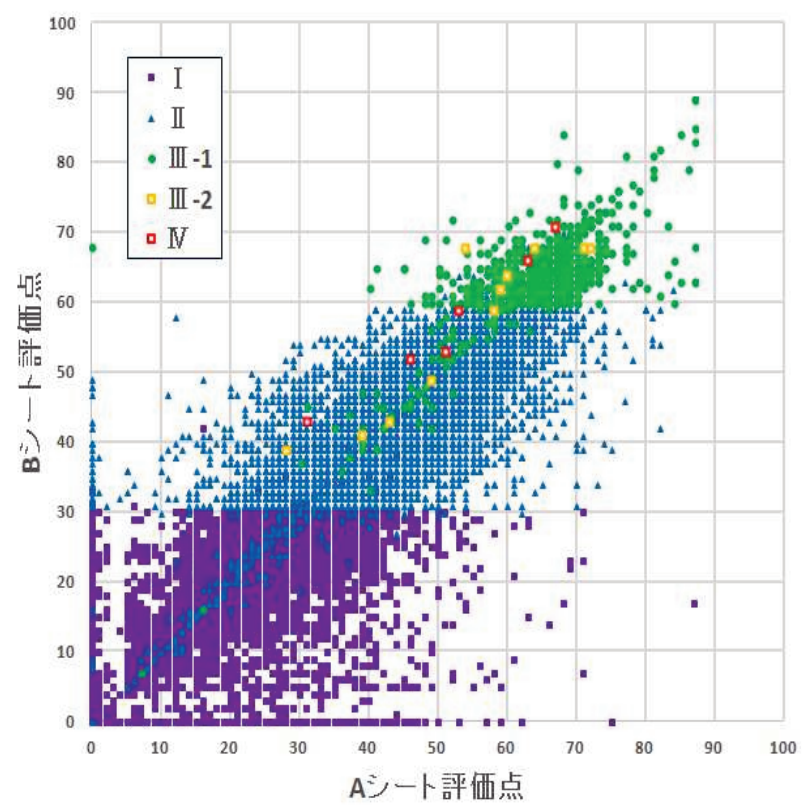

図-20 外力評価点と健全度ランクの関係 (山岳トンネル工法・矢板工法)

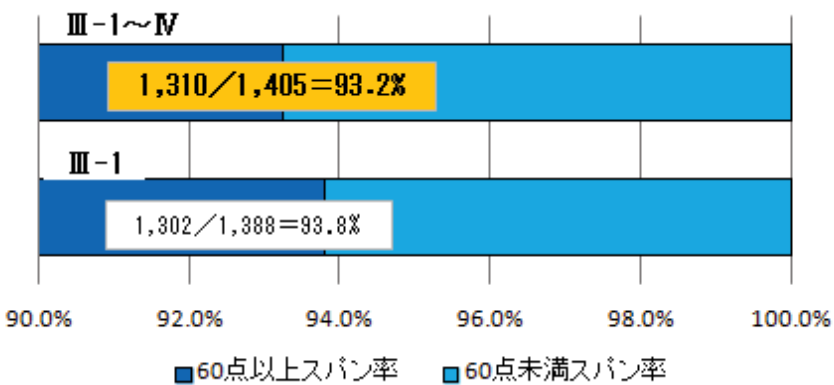

III-2

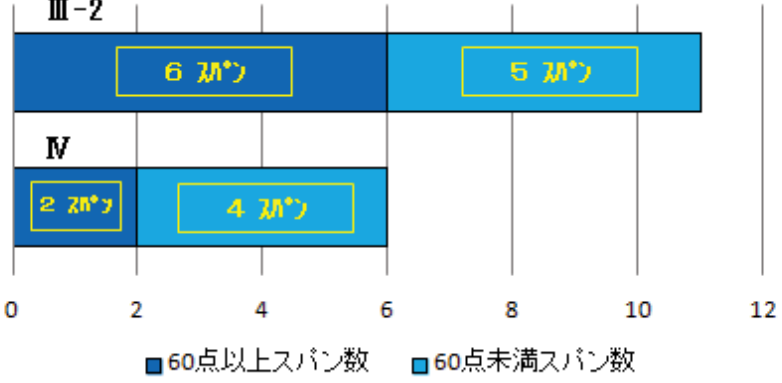

図-21＼cjkstart外力評価点による捕捉状況
スパンは 1405 スパン中 95.4\%の 1340 スパンであり，間 接的ではあるがはく落評価点の閾值は妥当であると判断 できる。しかし，前節(2)外力評価点と同様に全 1405 ス パン中 17 スパンと非常に少ないが，変状の進行状態の 評価がより重要となる「III-2」，「IV」のスパンでは 36 点以上が，それぞれ 11 スパン中 6 スパン (54.5\%)，6 スパン中 2 スパン $(33.3 \%)$ と 35 点以下のスパンが存在 している.これは外力評価点と同様に，スパン内に大き なひびわれがあっても，TCI で算出される評価点はひび われ幅，長さ，密度，分布が平準化されることから，進

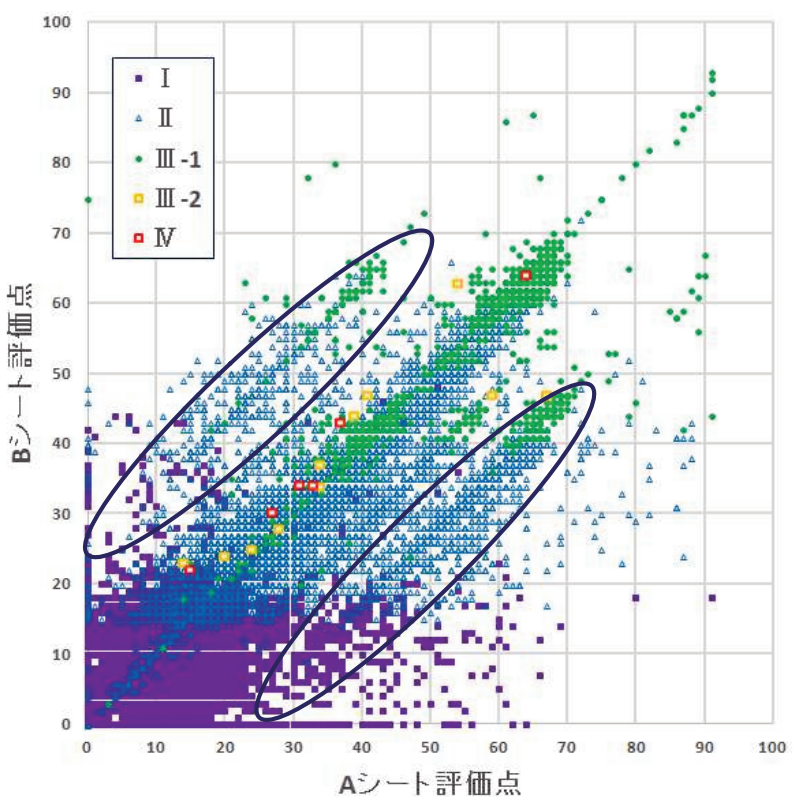

図-22 はく落評価点と健全度ランクの関係 (山岳トンネル工法・矢板工法)
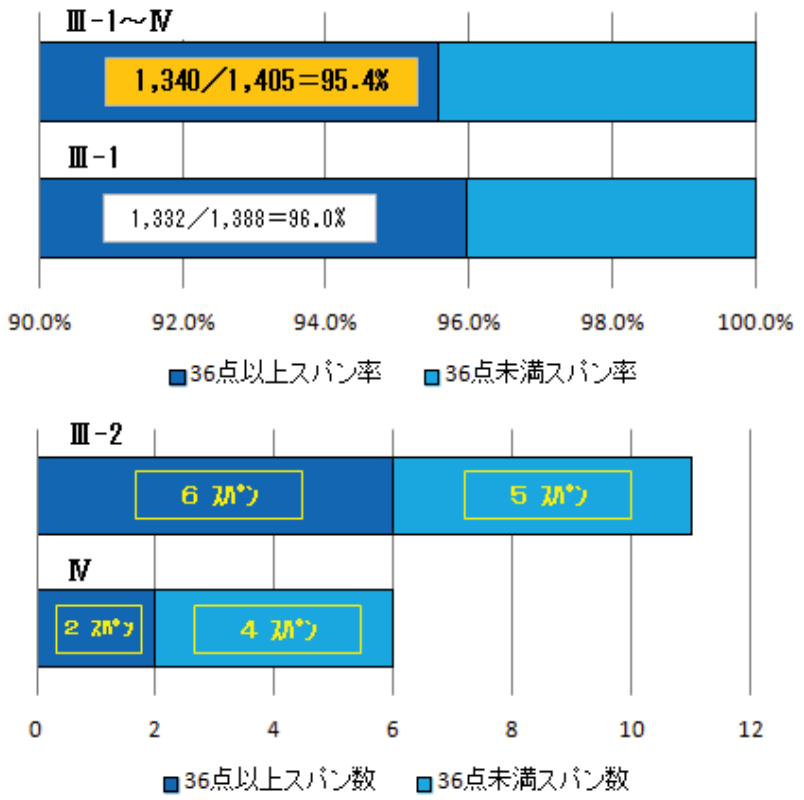

図-23 はく落評価点による捕捉状況 


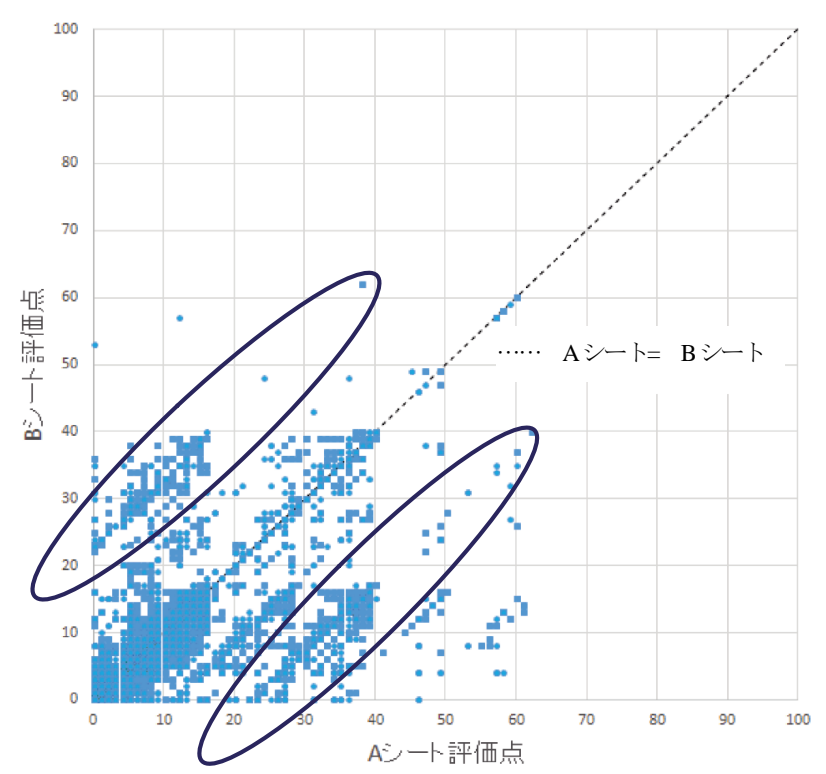

図-24 ひびわれパターンの夕に着目した健全度ランクとはく 落評価点の関係（山岳トンネル工法・矢板工法）

表-6 はく落判定におけるひび割れ評価点の配点 ${ }^{8)}$

\begin{tabular}{|c|c|c|c|c|c|}
\hline \multicolumn{2}{|c|}{ 観察項目 } & \multicolumn{2}{|c|}{ 判定区分 } & 外力 & はく落 \\
\hline \multirow{10}{*}{ 3パターン } & \multirow[t]{3}{*}{ 亀甲状 } & \multicolumn{2}{|l|}{ なし } & 0 & 0 \\
\hline & & \multicolumn{2}{|l|}{$1 \mathrm{~m}^{2}$ 未満 } & 7 & 11 \\
\hline & & \multicolumn{2}{|l|}{$1 \mathrm{~m}^{2}$ 以上 } & 14 & 22 \\
\hline & \multirow[t]{3}{*}{ 閉合型 } & \multirow{2}{*}{\multicolumn{2}{|c|}{$\mid$\begin{tabular}{|l} 
なし \\
長辺 $20 \mathrm{~cm}$ 未満
\end{tabular}}} & 0 & 0 \\
\hline & & & & 4 & 12 \\
\hline & & \multicolumn{2}{|c|}{ 長辺 $20 \mathrm{~cm}$ 以上 } & 7 & 23 \\
\hline & \multirow[t]{4}{*}{ 交差·分岐 } & なし & ない & 0 & 0 \\
\hline & & 5箇所未満 & 少ない & 2 & 4 \\
\hline & & 5 9箇所 & 中程度 & 3 & 8 \\
\hline & & 10箇所以上 & 刿, & 5 & 12 \\
\hline \multirow{4}{*}{\multicolumn{2}{|c|}{ 4.エフロレッセンス }} & \multirow{2}{*}{\multicolumn{2}{|c|}{\begin{tabular}{|l|} 
なし \\
小ない,
\end{tabular}}} & 0 & 0 \\
\hline & & & & 1 & 1 \\
\hline & & \multicolumn{2}{|c|}{ 中程度 } & 2 & 2 \\
\hline & & \multicolumn{2}{|c|}{\begin{tabular}{|l} 
多い(全面に分布) \\
な心
\end{tabular}} & 3 & 3 \\
\hline \multirow{3}{*}{\multicolumn{2}{|c|}{5 漏水 }} & \multirow{3}{*}{\multicolumn{2}{|c|}{ 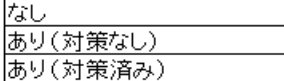 }} & 0 & 0 \\
\hline & & & & 2 & 2 \\
\hline & & & & 2 & 0 \\
\hline
\end{tabular}

行性の考慮が重要であると考えられる.

したがって, 外力評価点と同様にはく落評価点でも変 状の進行性を考慮した評価方法の検討を行えば，より精 度の向上が期待できる.

b) はく落評価点におけるひびわれパターンの発生傾向

図-20 と図-22 を比較すると, 図-20 の外力評価点に比 較して図-21 のはく落評価点は全体的に分布にばらつき があることがわかる，とくに，図-22 内に示した青丸で 囲んだ部分のように，線形に分布するグループが認めら れる.この発生要因を特定するため, 図-22 から TCI に より評価される「1.ひびわれ幅・長さ・分布」，「2.ひ びわれ方向性」の評価点をはく落評価点から差し引いた 結果を，図-24 に示寸．図中の破線（黒）は傾きが 1 の 直線であり，この直線付近にプロットされたスパンは点 検 $\mathrm{A}$ と点検 $\mathrm{B}$ における評価に差異がないことを表して いる. この図の青丸部分からわかるように図-22 とほぼ 同じパターンで分布している，このことから，表-6に 示寸 A，B シートにおけるデータシート部の，はく落判

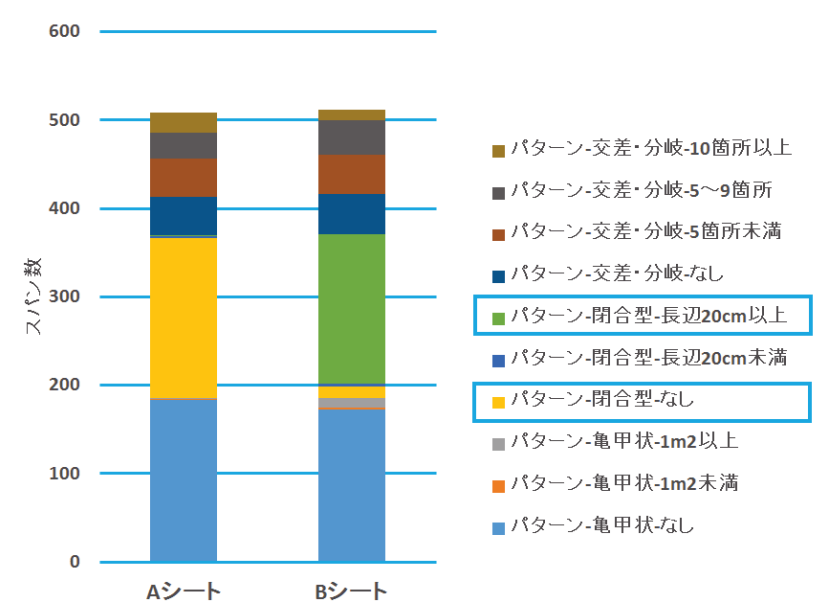

図-25 ひびわれパターン比較

(A シート $<$ B シートの場合)

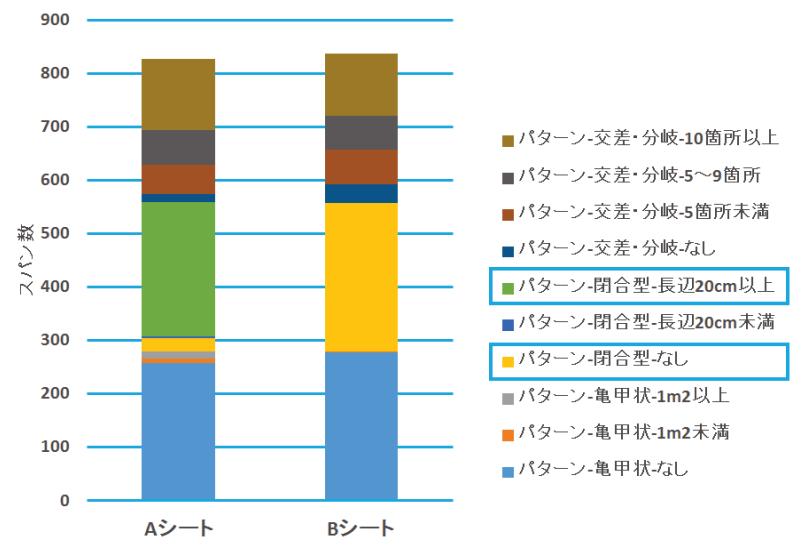

図-26 ひびわれパターン比較 (Aシート>B シートの場合)

定におけるひびわれ評価点のうち TCI で評価した以外の

「3.パターン」，「4. エフロレッセンス」，「5. 漏水」 の影響がその発生要因と考えられる.

表-6に示すはく落評価点の配点を見ると，3. パターン の，「亀甲状」，「閉合型」，「交差・分岐」において， 配点の開きが確認できる．たとえば点検 A で，閉合型 ひびわれを「なし」と判定したものの，点検 B で閉合 型ひびわれが「長辺 $20 \mathrm{~cm}$ 以上」と判定したスパンは, A シートと, B シートのはく落評価点差が 23 点と高く なるため, 配点の高い部分の判定の差が, 図-22 の青丸 部のように特徴的な分布が生じる要因と考えられる.

そこで，特徵的な分布の要因として，はく落評価点の 配点が高い「ひびわれパターン」について，点検 A と 点検 $\mathrm{B}$ の判定の違いについて個々の事例を分析する.

図-25 は，図-22 において，A シートより B シートの 方が評価点の高いスパンを抽出し，Aシートと B シート でひびわれパターンの判定に差異がないか分析した結果 である．図-25を見ると，ひびわれパターン項目の「閉 合型」は，黄色で示寸「なし」が A シートで 181 スパン 
に対し，B シートでは 13 スパンと大幅に減少するのに 対し，緑色で示す「長辺 $20 \mathrm{~cm}$ 以上」は，A シートでは 1 スパンであるにも関わらず， B シートでは 169 スパン と「閉合型」が増加していることがわかる。それに対し， ひびわれパターンの「亀甲状」と「交差・分岐」では大 きな判定の違いは見られない.

すなおち，はく落評価点において，Aシートより B シ 一トの方が, 評価点が高くなる覆工スパンは, 点検 $\mathrm{A}$ 実施時に「閉合型」を画像からでは認識しきれないこと が原因と考えられる.

図-26 は，図-25 とは逆に，図-22において，A シート より Bシートの方が評価点の低いスパンを抽出し, Aシ

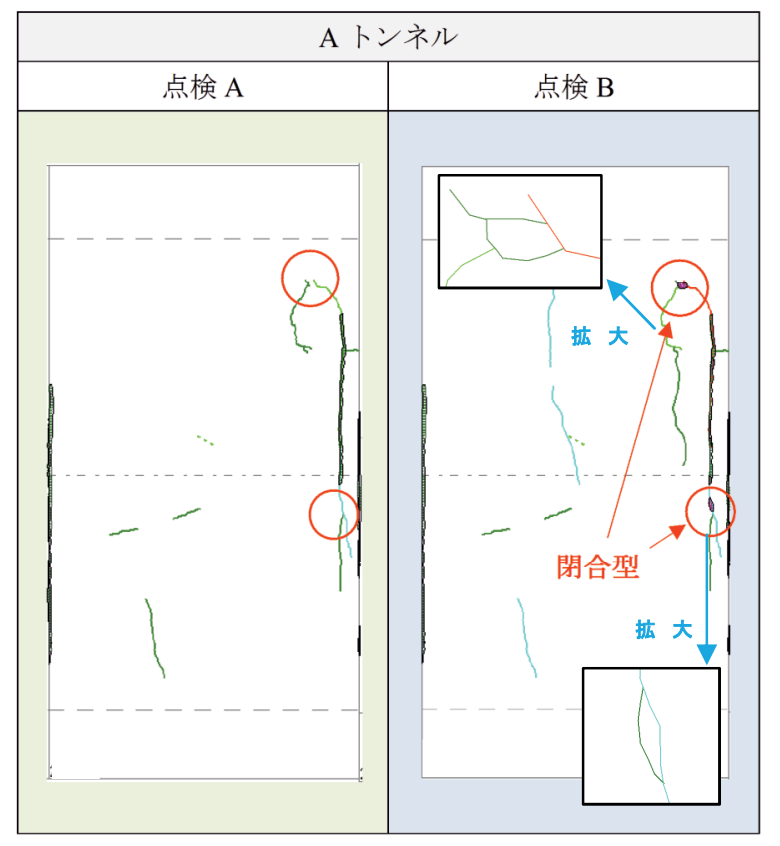

図-27 ひびわれ比較（点検 B : 閉合型ひびわれあり）

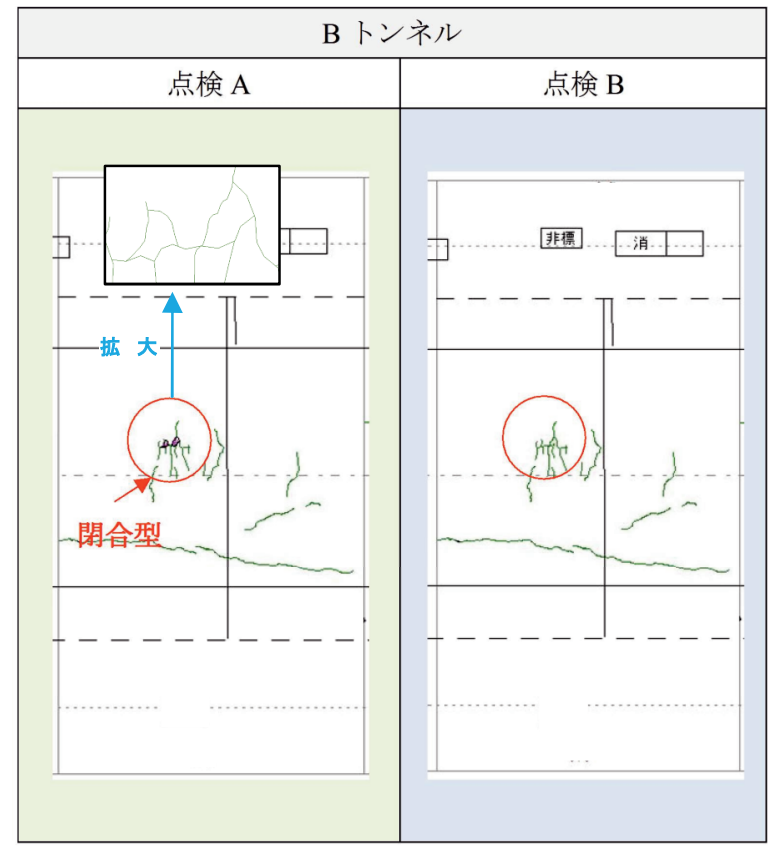

図-28 ひびわれ比較（点検 A : 閉合型ひびわれあり）
ートと B シートでひびわれパターンの判定の差異を分 析した結果である。この図から, 図-25 に示す B シート の方が評価点が高いものと同様に A シートと B シート でひびわれパターンの「亀甲状」「交差・分岐」では大 きな判定の違いは見られないことがわかる，ただし，パ ターン項目の「閉合型」は，「なし」が A シートで 25 スパン, B シートで 279 スパンと大幅に増加，「長辺 $20 \mathrm{~cm}$ 以上」が A シートで 252 スパンから B シートで 0 スパンと大幅に減少していることが分かる. 寸なわち, はく落評価点において，Aシートより Bシートの方が, 評価点が低くなる覆工スパンは，点検 $\mathrm{A}$ 実施時に「閉 合型」を過度に判定したものと考えられる.

図-27 に覆工画像に基づく机上点検である点検 A の際 は閉合ひびわれは確認されなかったが，実際に現地に赴 き，詳細点検をおこなう点検 $\mathrm{B}$ の際に閉合型ひびわれ が確認された事例，図-28 にはその逆の事例を示す。こ れらのことから，はく落評価点のばらつきは，「閉合型 ひびわれ」の判定が大きく影響していると考えられる.

また，この閉合型ひびわれの判定は，5.(1)「点検 Aの 結果に基づく点検 B 実施状況」に示す捕捉率にも影響 していると考えられる.

\section{6. まとめ}

高速道路トンネルの点検データを用いて各種分析・評 価を行い，現在，NEXCO が実施しているトンネル覆工 点検評価手法について検証した，その検証結果をまとめ ると次のようになる.

\section{(1) 点検結果の整理}

現在，NEXCO で実施している点検において覆工画像 撮影からひびわれ展開図を作成し，スパン単位で外力評 価点, はく落評価点を算出した. そして点検結果を,

「外力評価点」，「はく落評価点」それぞれに，スパン ごとの評価点数のヒストグラムを作成し，傾向を分析し た.

その結果，点検 $\mathrm{A}$ による閾值より抽出されたスパン 数よりも, 実際に重点点検スパンとして点検 $\mathrm{B}$ を行っ たスパン数が多く, 閾值による判断以外に特記事項等に より判断しているスパンもあることから, 閾值の適正化 とともに，特記事項の照査・整理により，より的確な点 検 Bの実施が可能になると考えられる.

\section{（2）評価点および健全度ランク分析}

外力評価点およびはく落評価点, 健全度ランクについ て，トンネル工法別にデータの特徵や傾向の把握および 分析を行った. 


\section{a) 外力評価点, はく落評価点}

外力評価点およびはく落評価点は, 点検 A の画像点 検による評価点と, 点検 $\mathrm{B}$ の近接目視による評価点を 散布図により比較した. 外力評価点は, 山岳トンネル工 法の方が，はく落評価点は矢板工法の方が，点検 $\mathrm{A}$ と 点検 B の評価点にばらつきがあった。これは，画像精 度とトンネル工法によるひびわれ特性の違いによるもの と考えられる.

\section{b) 健全度ランク}

山岳トンネル工法は健全度 I のスパンの割合が最も多 いのに対し, 矢板工法は健全度 II が最も多くなってお り，矢板工法は健全度が山岳トンネル工法より低い傾向 がある.これは，覆工も荷重を受け持つという矢板工法 の特徵と, 山岳トンネル工法に比較して施工から時間が たっているための, 経年劣化等による変状進行が要因と なっていると考えられる.

\section{(3) 閾値の検証}

各閾値設定項目に対し評価点, 健全度ランクの分析結 果を踏まえ，閾値の妥当性について検証した。また，は く落評価点の配点について，画像撮影による点検におけ る課題抽出を行った.

\section{a) 点検 $A$ による点検 $\mathrm{B}$ の実施状況と課題}

外力評価点とはく落評価点ともに，それぞれの間值で ある 60 点と 36 点により, 現場での点検 B をほぼカバー できることが判明し，閾值は妥当と判断できる．ただし， 下記c)に示すひびわれパターン項目の「閉合型」の認識 の改善および山岳トンネル工法，矢板工法（上半先進）, 矢板工法（側壁導坑）等のトンネルの施工方法の違いに よるひびわれの発生形態 9)を分類し，ひびわれパターン を把握し，特記事項に反映させることにより，点検 B の実施精度をより向上させることができると考えられる.

\section{b) 健全度ランクからみた評価点と課題}

健全度ランク「III-1」〜「V」に注目して分析した結 果，外力評価点およびはく落評価点の閾值は妥当之判断 できるが，変状の進行性をより考慮した健全度ランク

「III-2」，「IV」のスパンは，それぞれの閾值以下のス パンがある。これは，スパンに最大幅の大きなひびわれ があっても，TCI で算出される評価点はひびわれ幅，長 さ, 密度, 分布が平準化されるためと考えられ，そのた め, 変状の進行性を考慮した評価方法の検討が重要であ ると考えられる. 変状の進行性については, 覆工表面画 像撮影を基にした点検 $\mathrm{B}$ を複数回実施したトンネルに ついて, TCI 值 $\left(\times 10^{-5}\right)$ の全体の大きさを表す $\mathrm{F}_{0}$ の值 の「覆工スパンごとにおける $F_{0}$ の変動」，「時系列的 な $F_{0}$ 変動」に着目しての検討が有効であると考えられ る. また，建設時の地質や地形の影響，地す心゙り等の影 響による圧ざや，盤ぶくれ等の影響は TCIからは直接読
み取ることは難しいと想定されるため，これらについて は特記事項等の活用する検討を行う必要があると考えら れる.

c) はく落評価点の課題

はく落評価点の分布状況から, 点検 $\mathrm{A}$ の画像点検時 において，ひびわれパターン項目の「閉合型」を認識で きていない，あるいは，「閉合型」を過度に判定してい る事例があることがわかった。これら閉合部は，複数の ひびわれが近接して存在しているため, 画像精度および 人によるひびわれ抽出時の誤認等により, 認識しきれな いためと推測されることから, 画像の解像度および精度 を改善する他，ひびわれを認識できなかった原因の特定 および分析を行うことが重要であることから，点検 B の精度向上に関して, 現場技術者の健全度判定と点検 B の結果を比較・分析することにより，ひびわれを認識で きなかった原因を調べることや，今後はく落の原因とな るひびわれや，そのパターンにはどのような特徵がある か調査し，画像等の点検手法による，はく落発生個所を 予測するシステム構築を検討していくことが点検の効率 化に重要であると考える.

\section{参考文献}

1) 東日本 - 中日本 - 西日本高速道路（株）：保全点検 要領 構造物編, p. $158,2017$.

2）重田佳幸, 飛田敏行, 亀村勝美, 進士正人, 吉武 勇, 中川浩二 : ひびわれ方向性を考慮した覆工コン クリートの健全度評価, 土木学会論文集 F, Vol.62, No.4, pp.628-632, 2006.

3) 東日本・中日本・西日本高速道路（株）：保全点検 要領 構造物編, p.137, 2017.

4) 東日本・中日本・西日本高速道路（株）：保全点検 要領 構造物編, p.138, 2017.

5) 山田隆昭, 佐野信夫, 馬場弘二, 吉武 勇, 中川浩 二：トンネル覆エコンクリートの定量的な健全度評 価基準，土木学会論文集 F, Vol.63，No.1，pp.86-96， 2007.

6) 川上浩一, 小西真治, 村上哲哉, 久保昌史, 中山聡 子 : 赤外線熱計測による地下鉄シールドトンネル内 中子型セグメント表層コンクリートの浮き検出，土 木学会論文集 F1 (トンネル工学)，Vol.71，No.3 (特集号), pp.I_112-I_121，2016.

7) 日本道路協会 : 道路トンネル維持管理便覧【本体工 編】, pp.195-234, 2015.

8) 山田隆昭, 佐野信夫, 重田佳幸, 吉武 勇, 西村和 夫 : ひびわれ指数を用いたトンネル覆エコンクリー 卜の健全度評価法の構築, 土木学会論文集 $\mathrm{F}$, Vol.65, No.1, pp.11-16, 2009.

9) 前田佳克, 八木弘, 海瀬忍, 増田弘明, 水野希典, 重田佳幸, 前田洸樹 : ひびわれ指数（TCI）を用い た覆工に発生するひびわれ形態の整理，トンネル工 学報告書, 第 26 巻, I-30, 2016.

(2017.7.25 受付) 


\title{
VERIFICATION ON QUANTITATIVE HEALTH MONITORING METHOD OF TUNNEL CONCRETE LINING
}

\author{
Shinobu KAISE, Tetsuo ITO, Hiroshi YAGI, Maresuke MIZUNO, Kouki MAEDA \\ and Masato SHINJI
}

Monitoring system of Japan expressway corporation (NEXCO) consists two stages. The first stage is the screening system by using tunnel lining photo image at the periodic tunnel health inspection. The second stage is the onsite detailed inspection by engineer. The main evaluation item of both system is called evaluation value effected by external force and exfoliation based on Tunnel lining Crack Index (TCI). In this research, inspection results over 85,000 lining spans managed by NEXCO was analyzed for the purpose of high accuracy and efficiency of tunnel health monitoring system for expressway. In the data analysis, it was found that there is a high relationship with tendency between the first and second stage. In addition, a comparative analysis of the both stage is performed. The practicality of the current inspection system is high, the efficiency of detailed inspection needs to be examined in the future. 